\title{
Detection of transgenic maize Cry1 Ab protein subjected to ruminal digestion
}

\author{
J.L. Jacobs ${ }^{1}$, F. Diez-Gonzalez ${ }^{2}$, M.D. Stern ${ }^{3}$ and R.L. Phillips ${ }^{1}$ \\ ${ }^{1}$ Department of Agronomy and Plant Genetics, \\ ${ }^{2}$ Department of Food Science and Nutrition, \\ ${ }^{3}$ Department of Animal Science \\ University of Minnesota, St. Paul, MN 55108, USA
}

(Received 7 May 2005; accepted 17 October 2005)

\begin{abstract}
This research determined the extent of ruminal degradation of a transgenic protein $(\mathrm{Cry} 1 \mathrm{Ab})$ expressed in kernels of maize (Zea mays) cultivar DKC53-32. Cracked kernels of transgenic maize $(\mathrm{Bt}+)$ were subjected to rumen digestion using in situ experiments with two ruminally cannulated Holstein cows. A non-transgenic maize cultivar (Bt-) was used as a control for crude protein (CP) degradation. $\mathrm{CP}$ and Cry1 A concentrations from dacron polyester bags inserted in the rumen were determined for $48 \mathrm{~h}$. The Bt- cultivar had greater $\mathrm{CP}$ content $(\mathrm{P}<0.05)$ than the $\mathrm{Bt}+$ maize, but no difference $(\mathrm{P}>0.05)$ was found in ruminal degradable protein and the $\mathrm{CP}$ rate of degradation. The Cry $1 \mathrm{Ab}$ protein was detected throughout ruminal digestion. The amount of Cry $1 \mathrm{Ab}$ protein remaining after 16 and $24 \mathrm{~h}$ of ruminal degradation was 85 and $60 \%$, respectively. These results indicated that a significant fraction of Cry $1 \mathrm{Ab}$ protein was not digested in the rumen. This is the first report of the rumen degradation rate of a transgenic protein.
\end{abstract}

KEY WORDS: Zea mays, genetically modified, rumen digestion, Bt maize, cattle, Cry1 Ab protein

\section{INTRODUCTION}

Cattle in the United States are fed diets that are predominantly based on maize and other cereal grains. Maize is an ideal feed for cattle because of the high starch content (0.6-0.8 $\mathrm{g} \mathrm{g}^{-1}$ dry matter) that provides a rich source of energy (Kotarski et al., 1992; McCleary et al., 1994). Approximately 55 to $60 \%$ of the protein in

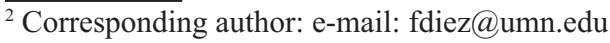


maize is not degraded in the rumen and as much as $40 \%$ can reach the large intestine (Philippeau et al., 1999).

The rate of ruminal digestion of maize depends on the physical form of the grain (Passini et al., 2004). Cracked maize, obtained by a mild grinding process is the most common form of maize kernels used for cattle operations in the United States. Cracked maize is preferred over whole maize kernels because the maize digestibility is increased (Lykos and Varga, 1995). Besides the physical form of maize kernels, there are differences in rumen digestibility due to maize cultivars. Variation in digestibility among cultivars is mostly related to degradation of plant cell wall and their breakableness susceptibility (Barriere et al., 2003, 2004).

Most research on the feeding of transgenic crops to animals is focused on identifying nutritional or toxic effects (Hammond et al., 1996; Flachowsky et al., 2005). The only transgenic protein that has been extensively studied for its resistance to digestion is the Bt-toxin, but little is known about its resistance to degradation in the rumen. Bacillus thuringiensis (Bt) is a naturally occurring soil bacterium that produces a toxic protein $(\mathrm{Cry} 1 \mathrm{Ab})$ that kills two Lepidoptera insects: the European maize borer and the southwestern maize borer (Hyde et al., 1999). Maize hybrids were genetically engineered to express the Bt toxin (Cry1 Ab) in the 1980s and were made commercially available in the mid-1990s. The addition of a transgene to the maize genome did not seem to influence digestibility in cattle. A study by Donkin et al. (2003) showed that there was no difference in ruminal digestibility between transgenic Bt-maize varieties and a non-transgenic control variety. Intrinsic background genetics of the maize had a more consistent impact on performance of the plant and cattle digestibility than did the presence of the Bt trait (Folmer et al., 2002; Rossi et al., 2003).

Detection of transgenic proteins during digestion in cattle has received little study. After 4 weeks of feeding Bt-maize, Einspanier et al. (2004), detected the presence of DNA and protein of the Cry1 Ab gene throughout the gastrointestinal tract of cattle. The objective of this research was to determine the extent of degradation of Cry $1 \mathrm{Ab}$, an expressed transgenic protein, during rumen digestion, and to examine if cracked maize could be a viable delivery vehicle of transgenic proteins for ruminant animals.

\section{MATERIAL AND METHODS}

Two maize cultivars were used in this study. The non-transgenic cultivar (Bt) was the inbred A188 (University of Minnesota, St. Paul, MN, USA), while the transgenic cultivar $(\mathrm{Bt}+$ ) DKC53-32 (Monsanto, St. Louis, MO, USA) contained the Mon810 Bt event. Because the parent cultivar of DKC53-32 was not available to the public, an unrelated and non-transgenic maize cultivar, A188 line, was used for 
comparison purposes for the rate of protein degradation. The Bt- maize was planted, grown, self-pollinated and harvested during the summer of 2002 at the University of Minnesota St. Paul research station. The $\mathrm{Bt}+$ maize was planted, grown, open pollinated and harvested in 2002 at Odland Farm (Webster City, Iowa, USA).

The two maize cultivars were cracked using a Wiley mill with no screen. Kernel size distribution was determined by placing the $\mathrm{Bt}-$ and $\mathrm{Bt}+$ samples through a series of four-square hole USA standard testing sieves (VMR Scientific, Inc, West Chester, PA) (Table 1).

TABLE 1

Size distribution of cracked Bt- and $\mathrm{Bt}+$ maize samples using American Society for Testing and Material international (ASTM) mesh sieves

\begin{tabular}{lrc}
\hline Sieve & \multicolumn{2}{c}{ \% Retention } \\
\cline { 2 - 3 } Mesh No. & $\mathrm{Bt}-$ & $\mathrm{Bt}+$ \\
\hline No. $8(2.38 \mathrm{~mm})$ & 71.6 & 79.6 \\
No. $20(0.841 \mathrm{~mm})$ & 20.1 & 14.0 \\
No. $30(0.595 \mathrm{~mm})$ & 2.8 & 1.9 \\
No. $80(0.177 \mathrm{~mm})$ & 4.9 & 4.0 \\
Passed thru No. 80 & 0.6 & 0.4 \\
\hline
\end{tabular}

a openings per linear inch

The in situ experiments were conducted in April 2003 on two lactating, ruminally cannulated Holstein heifers. The daily ration fed to the heifers consisted of maize silage, lucerne hay and grain mixture. To determine the degradability of each maize sample, the dacron polyester bag technique was used (Stern and Satter, 1984). This method involved placing $2.0 \mathrm{~g}$ of the cracked Bt- or Bt+ samples into a $6 \times 10 \mathrm{~cm}$ dacron polyester bag with an average pore size of $52 \mu \mathrm{m}$. The bags were sealed. All bags containing samples were submerged in warm water $\left(37^{\circ} \mathrm{C}\right)$ for 15 min and then placed inside the ventral sac of the rumen. Sample bags in duplicate were removed from the rumen at $0,2,4,8,16,24$ and $48 \mathrm{~h}$ of ruminal exposure. All exposure times were evaluated in duplicate. After removal of sample bags from the rumen, bags were rinsed with tap water and dried at $60^{\circ} \mathrm{C}$ for $48 \mathrm{~h}$.

Protein content of residue remaining in bags was determined according to the Kjeldahl method (AOAC, 1990). Ruminal degradability of protein was calculated according to the Mathers and Miller equation (1981), assuming a ruminal solids passage rate of $0.06 \mathrm{~h}^{-1}$. Potential ruminal degradability $(\mathrm{Y})$ is expressed in the following equation:

$$
\mathrm{Y}=a+b\left(\mathrm{~K}_{\mathrm{d}} / \mathrm{K}_{\mathrm{r}}+\mathrm{K}_{\mathrm{d}}\right)
$$

where $a$ represents the soluble fraction, $b$ represent the insoluble fraction, $\mathrm{K}_{\mathrm{d}}$ is the rate of nitrogen loss, and $\mathrm{K}_{\mathrm{r}}$ is the rate of passage of the non-degraded protein $\left(0.06 \mathrm{~h}^{-1}\right)$ from the rumen. 
The Cry $1 \mathrm{Ab}$ protein was determined quantitatively using GMO check $^{\mathrm{TM}} \mathrm{Bt}$ Maize test kit (Strategic Diagnostics Inc, Newark, DE, USA), an ELISA method, according to the manufacturer's instructions. Remaining samples after digestion were weighed and cracked samples were further ground with mortar and pestle. A commercial control $\mathrm{Bt}+$ maize cultivar protein was used to construct a standard curve of Bt-protein fraction ( $\mathrm{ng} \mathrm{g}^{-1}$ total protein) vs absorbance at $450 \mathrm{~nm}$ from 0 to $2 \% \mathrm{Bt}$-protein/total protein.

Comparisons between $\mathrm{Bt}+$ and $\mathrm{Bt}$ - maize samples, were analysed with a twotailed t-test procedure using SAS statistical package and significant differences were determined based on a $\mathrm{P}<0.05$ (SAS Institute, 1997).

\section{RESULTS}

\section{Ruminal digestibility}

Average crude protein content $(\mathrm{CP})$ of the cracked $\mathrm{Bt}+$ maize samples was only $64 \%$ of the $\mathrm{CP}$ of the Bt- cultivar (Table 2). There was a significant difference (65.7 vs $116.7 \mathrm{~g} \mathrm{~kg}^{-1} ; \mathrm{P}<0.05$ ) between the $\mathrm{CP}$ for the two maize cultivars with approximately $40 \mathrm{~g} \mathrm{~kg}^{-1}$ more crude protein in the Bt- maize. The Mathers and Miller equation used to calculate the percentage of ruminally degradable protein showed that the Bt- sample degraded 7\% more than the Bt+ sample, however this observation was not a significant difference between treatments $(\mathrm{P}>0.05)$. Bt+ samples had less initial CP solubilization than the Bt- variety, but there was no difference $(\mathrm{P}>0.05)$. Ruminal degradation rates of crude protein were similar between the two maize cultivars.

\section{Crude protein degradation}

Bags containing cracked samples had a dry matter loss after they were immersed in water, before insertion into the rumen. This loss, shown in the solubility calculation (Table 2) was adjusted to reflect the true percent loss over time (Figure 1). Although the percent crude protein in all of the $\mathrm{Bt}+$ maize samples decreased during the 48 -h incubation in the rumen, the decrease was not proportional between each time point. For the first $16 \mathrm{~h}$, the decrease was gradual, with only $11 \%$ of the total crude protein lost. At $16 \mathrm{~h}$, the change was greater, with a loss of $59 \%$. After $24 \mathrm{~h}$ the cracked $\mathrm{Bt}+$ sample had only been $38 \%$ digested and by $48 \mathrm{~h} 70 \%$ of the crude protein was digested. 
TABLE 2

Comparison of $\mathrm{Bt}+$ and $\mathrm{Bt}-$ maize for crude protein $(\mathrm{CP})$, ruminal degradable protein (RDP) and ruminal undegradable protein (RUP), crude protein solubility and crude protein degradation rate. Averages and standard deviation values shown are the result of 4 replicate measurements

\begin{tabular}{lccccc}
\hline \multirow{2}{*}{ Sample } & \multirow{2}{*}{$\begin{array}{c}\text { Crude protein } \\
\mathrm{g} \mathrm{kg}^{-1} \text { feed }\end{array}$} & \multirow{2}{*}{$\begin{array}{c}\text { RDP } \\
\text { \% of CP }\end{array}$} & \begin{tabular}{c}
\multirow{2}{*}{ RUP } \\
\% of CP
\end{tabular} & $\begin{array}{c}\text { Colubility } \\
\%\end{array}$ & $\begin{array}{c}\text { degradation } \\
\mathrm{h}^{-1}\end{array}$ \\
\hline $\mathrm{Bt}+$ Maize & $75.7^{\mathrm{A}} \pm 7.1$ & $29.8^{\mathrm{A}} \pm 5.6$ & 70.2 & $4.4^{\mathrm{A}} \pm 1.2$ & $1.64^{\mathrm{A}} \pm 0.01$ \\
$\mathrm{Bt}$ - Maize & $116.7^{\mathrm{B}} \pm 3.5$ & $37.1^{\mathrm{A}} \pm 5.0$ & 62.9 & $7.5^{\mathrm{A}} \pm 3.8$ & $1.62^{\mathrm{A}} \pm 0.03$ \\
\hline
\end{tabular}

${ }^{\mathrm{a}} \mathrm{RUP}=100 \%-\mathrm{RDP}$

different subscripts indicate a statistically significant difference based on a $\mathrm{P}<0.05$

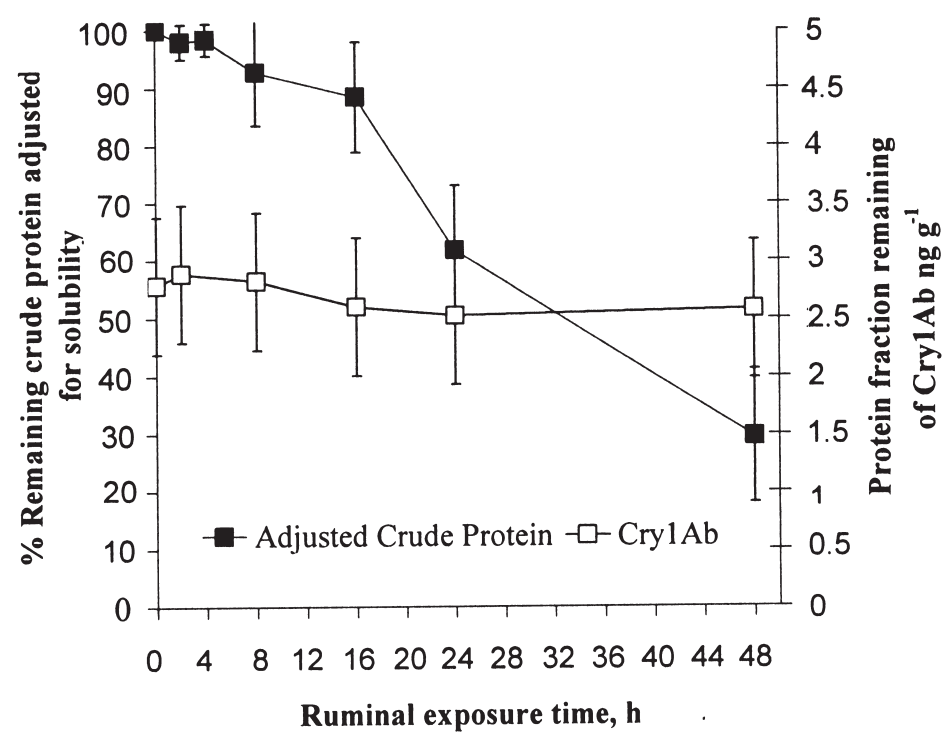

Figure 1. Effect of time of ruminal incubation on the remaining crude protein and the specific Cryl $\mathrm{Ab}$ content of $\mathrm{Bt}+$ maize samples

\section{Determination of CrylAb protein concentration}

The $\mathrm{Cry} 1 \mathrm{Ab}$ protein content was measured using an enzyme-linked immunosorbent assay for $\mathrm{Bt}+$ and $\mathrm{Bt}-$ samples. The $\mathrm{Cry} 1 \mathrm{Ab}$ protein was detected for all time points for all $\mathrm{Bt}+$ cracked samples, but not for Bt- cracked samples. When the Cry $1 \mathrm{Ab}$ protein content was divided by the amount of remaining crude protein at each time period, this specific ratio was relatively constant between 2.6 and $2.9 \mathrm{ng} \mathrm{g}^{-1}$ protein throughout the ruminal incubation (Figure 1). Based on the specific Cry $1 \mathrm{Ab}$ concentration and the percent remaining crude protein after $16 \mathrm{~h}$, more than $85 \%$ of the initial amount of Cry $1 \mathrm{Ab}$ protein remained. 


\section{DISCUSSION}

\section{Ruminal digestibility}

This research found that there was more initial crude protein for the Bt-sample $\left(116.7 \mathrm{~g} \mathrm{~kg}^{-1}\right)$ than the $\mathrm{Bt}+$ sample $\left(75.7 \mathrm{~g} \mathrm{~kg}^{-1}\right)$. This difference was not surprising because it is common for crude protein differences to exist among maize cultivars. It is widely recognized that similar genetic backgrounds of a $\mathrm{Bt}+$ and a $\mathrm{Bt}-$ cultivar may vary in their crude protein contents (Masoero et al., 1999), among cultivars (Folmer et al., 2002) and even between ears and leaves of the same cultivar (Masoero et al., 1999). The lower crude protein level of $\mathrm{Bt}+$ compared with $\mathrm{Bt}-$ is likely associated with dry matter yield differences. If there is significantly less dry matter, the plant will focus its growth on kernel filling instead of vegetative growth.

Even though differences were found between initial crude protein in the $\mathrm{Bt}+$ and Bt- samples, there were no differences found for ruminal degradable protein or rate of crude protein digestion. Rossi et al. (2003) found a faster degradation rate of $\mathrm{CP}$ for $\mathrm{Bt}$ - than $\mathrm{Bt}+$, and suggested that because there was no compositional difference, that the difference could have been due to other factors, such as particle size differences. Passini et al. (2004) indicated that the extent of grinding had an effect on CP degradability. In the current study, the potential difference in degradation rate due to particle size distribution was prevented by standardizing the particle size distribution (Table 1).

\section{Crude protein degradation}

Crude protein degradation decreased over time, with the greatest degradation occurring between 16 and $24 \mathrm{~h}$ (approximately $20 \mathrm{~g} \mathrm{~kg}^{-1}$ ). Between 8 and $24 \mathrm{~h}$, there was a $31 \%$ change in crude protein values. A study by Rossi et al. (2003), observed a much larger change of $65 \%$ for the same time period, which is expected when kernels are ground through a $2 \mathrm{~mm}$ screen, because grinding will increase ruminal degradation rate (Michalet-Doreau and Cerneau, 1991).

The in situ dacron polyester bag technique is a simple, rapid and low cost method allowing for measurement of nitrogen $(\mathrm{N})$ loss in the rumen, but there are numerous factors that might alter the outcome and could explain inconsistent crude protein degradation. Using the dacron polyester bag technique, Arieli et al. (1999), compared degradability of different feed ingredients and reported an average degradability of crude protein from maize grain of $2.1 \% \mathrm{~h}^{-1}(\mathrm{SD}=1.1)$. This value was only $28 \%$ greater than values reported in the current study, but due to a large standard deviation, this difference would not be significantly different 
$(\mathrm{P}>0.05)$ in our study. In both studies, particle size was predominately $2 \mathrm{~mm}$, which could explain similarities in results.

\section{Determination of CrylAb protein concentration}

Several publications evaluated the use of transgenic crops as feeds for livestock animals. Daenicke et al. (1999), detected no differences in digestibility between $\mathrm{Bt}+$ and $\mathrm{Bt}$ - maize. A more recent report calculated a short-term increase of $7 \%$ in degradability of total protein of the $\mathrm{Bt}+$ variety compared with the control maize (Rossi et al., 2003). Using an in situ technique similar to the one used by Rossi et al. (2003), we showed no significant differences $(\mathrm{P}>0.05)$ in ruminal degradable protein or the rate of crude protein degradation.

Because of the potential environmental and food safety impact, the transfer of genetic material from transgenic crops to animals has also received attention from researchers. A research group from Japan detected the Cry1 Ab and Cry9 genes in the digestive contents throughout the gastrointestinal tract of calves and pigs in two separate studies (Chowdhury et al., 2003b, 2004). The DNA of both Bt-toxin genes was detected experimentally in the faecal samples of more than $25 \%$ of pigs and $50 \%$ of calves. However, none of the recombinant DNA fragments were detected in intestinal epithelia, peripheral blood mononuclear cells and any of the tissue samples of organs associated with the gastrointestinal tract.

Despite the fact that many of the commercially available transgenic Bt-toxin varieties have been engineered to increase resistance to maize borers, very little is known about the rate of digestion in the rumen. In the first article that reported the detection of Cry $1 \mathrm{Ab}$ protein in the gastrointestinal tract of calves fed maize Bt11, Chowdhury et al. (2003a), quantified this protein in the digesta of the rumen, abomasum, caecum and rectum, as well as in faeces within $18 \mathrm{~h}$ after feeding. A significant variability among cattle was observed, but the average Cry $1 \mathrm{Ab}$ concentration in the rumen ( $38 \mathrm{ppb}$ ) was very similar to the concentration detected in faecal samples $(42 \mathrm{ppb})$. The authors also reported that the Cry1Ab protein gradually disappeared from faecal samples after 14 days, but they did not measure the rate of ruminal degradation. The present research assessed the extent of ruminal degradation and established that the Cry $1 \mathrm{Ab}$ protein digested at a similar rate as the total crude protein in maize.

In another publication, Einspanier et al. (2004), reported the detection of transgenic Cry $1 \mathrm{Ab}$ protein in the digesta of most gastrointestinal tract sites in cattle. In contrast, Chowdhury et al. (2003a), observed a reduction in the Cryl Ab protein concentration from $0.75 \mathrm{ng} \mathrm{g}^{-1}$ protein in the rumen to $0.22 \mathrm{ng} \mathrm{g}^{-1}$ protein in the colon. This result indicated that approximately $30 \%$ of the transgenic protein reached the large intestine. Both reports did not determine the rate of ruminal 
degradation. Our study clearly indicated that a significant fraction of Cry $1 \mathrm{Ab}$ protein was not digested in the rumen, but at the same time its degradation rate appeared to be very similar to the degradation of the total maize protein.

\section{CONCLUSIONS}

Our findings indicate that the Cry $1 \mathrm{Ab}$ protein in a transgenic maize cultivar is degraded at similar rates as the total maize protein in the rumen of cattle, but a substantial fraction of the Bt-toxin remains undigested after $24 \mathrm{~h}$.

\section{ACKNOWLEDGEMENTS}

Funding for this project was provided by a McKnight Presidential Chair in Genomics, University of Minnesota.

\section{REFERENCES}

AOAC, 1990. Official Methods of Analysis, Association of Official Analytical Chemists.15th Edition. Arlington, VA

Arieli A., Shahar K., Mabjeesh S.J., Zamwel S., Sklan D., 1999. Estimation of the digestible energy of ruminant feedstuffs by the combined bag technique. J. Dairy Sci. 82, 566-573

Barriere Y., Emile J.C., Surault F., 2003. Genetic variation of maize silage ingestibility in dairy cattle. Anim. Res. 52, 489-500

Barriere Y., Goncalves G.D., Emile J.C., Lefevre B., 2004. Higher intake of DK265 corn silage by dairy cattle. J. Dairy Sci. 87, 1439-1445

Chowdhury E.H., Mikami O., Murata H., Sultana P., Shimada N., Yoshioka M., Guruge K.S., Yamamoto S., Miyazaki S., Yamanaka N., Nakajima Y., 2004. Fate of maize intrinsic and recombinant genes in calves fed genetically modified maize Bt11. J. Food Protect. 67, 365-370

Chowdhury E.H., Mikami O., Nakajima Y., Kuribara H., Hino A., 2003a. Detection of genetically modified maize DNA fragments in the intestinal contents of pigs fed StarLink (TM) CBH351. Vet. Hum. Toxicol. 45, 95-96

Chowdhury E.H., Shimada N., Murata H., Mikami O., Sultana P., Miyazaki S., Yoshioka M., Yamanaka N., Hirai N., Nakajima Y., 2003b. Detection of Cry1Ab protein in gastrointestinal contents but not visceral organs of genetically modified Bt11-fed calves. Vet. Hum. Toxicol. 45, 72-75

Daenicke R., Aulrich K., Flachowsky G., 1999. GMO in feeds: Bt has no impact on nutritionalphysiological characteristics (in German). Mais 4, 135-137

Donkin S.S., Velez J.C., Totten A.K., Stanisiewski E.P., Hartnell G.F., 2003. Effects of feeding silage and grain from glyphosate-tolerant or insect-protected corn hybrids on feed intake, ruminal digestion, and milk production in dairy cattle. J. Dairy Sci. 86, 1780-1788

Einspanier R., Lutz B., Rief S., Berezina O., Zverlov V., Schwarz W., Mayer J., 2004. Tracing residual recombinant feed molecules during digestion and rumen bacterial diversity in cattle fed transgene maize. Eur. Food Res. Technol. 218, 269-273 
Flachowsky Y., Chessson A., Aulrick K., 2005. Animal nutrition with feeds from genetically modified plants. Arch. Anim. Nutr. 59, 1-41

Folmer J.D., Grant R.J., Milton C.T., Beck J., 2002. Utilization of Bt corn residues by grazing beef steers and Bt corn silage and grain by growing beef cattle and lactating dairy cows. J. Anim. Sci. $80,1352-1361$

Hammond B.G., Vicini J.L., Hartnell G.F., Naylor M.W., Knight C.D., Robinson E.D., Fuchs R.L., 1996. The feeding value of soybeans fed to rats, chickens, catfish and dairy cattle is not altered by genetic incorporation of glyphosate tolerance. J. Nutr. 126, 717-727

Hyde J., Martin M.A., Preckel A.T., Edwards C.R., 1999. The economics of Bt corn: valuing protection from the European corn borer. Rev. Agr. Econ. 21, 442-454

Kotarski S.F., Waniska R.D., Thurn K.K., 1992. Starch hydrolysis by the ruminal microflora. J. Nutr. 22, $178-190$

Lykos T., Varga G., 1995. Effects of processing method on degradation characteristics of protein and carbohydrate sources in situ. J. Dairy Sci. 78, 1789-1801

Masoero F., Moschini M., Rossi F., Prandini A., Pietri A., 1999. Nutritive value, mycotoxin contamination and in vitro rumen fermentation of normal and genetically modified corn (cry1A(b)) grown in northern Italy. Maydica 44, 205-209

Mathers J.C., Miller E.L., 1981. Quantitative studies of food protein degradation and the energetic efficiency of microbial protein synthesis in the rumen of sheep given chopped lucerne and rolled barley. Brit. J. Nutr. 45, 587-604

McCleary B.V., Solah V., Gibson T.S., 1994. Quantitative measurement of total starch in cereal flour products. J. Cereal Sci. 20, 51-58

Michalet-Doreau B., Cerneau P., 1991. Influence of foodstuff particle size on in situ degradation of nitrogen in the rumen. Anim. Feed Sci. Tech. 35, 69-81

Passini R., Borgatti L.M.O., Ferreira F.A., Rodrigues P.H.M., 2004. Degradability of differently processed corn grain in bovine rumen (in Portuguese). Pesquisa Agr. Brasil. 39, 271-276

Philippeau C., Martin C., Michalet-Doreau B., 1999. Influence of grain source on ruminal characteristics and rate, site, and extent of digestion in beef steers. J. Anim. Sci. 77, 1587-1596

Rossi F., Moschini M., Fiorentini L., Masoero F., Piva G., 2003. Analytical composition and rumen degradability of isogenic and transgenic corn varieties. J. Sci. Food Agr. 83, 1337-1341

SAS Institute, 1997. SAS/STAT ${ }^{(\mathrm{R})}$ User's Guide: Statistics, Release 6.04 edition. SAS Institute Inc, Cary, NC

Stern M.D., Satter L.D., 1984. Evaluation of nitrogen solubility and the dacron bag technique as methods for estimating protein degradation in the rumen. J. Anim. Sci. 58, 714-724 


\section{STRESZCZENIE}

\section{Wykorzystanie białka transgenicznej kukurydzy Cry1Ab poddanego trawieniu w żwaczu}

Celem badań było określenie stopnia degradacji w żwaczu białka transgenicznej kukurydzy (Cry1Ab), odmiany DKC53-32. Rozdrobione ziarna transgenicznej kukurydzy $(\mathrm{Bt}+)$ trawione były w żwaczu przez 48 godz. u dwóch przetokowanych krów holsztyńskich w warunkach in situ. Jako kontrolę stosowano odmianę kukurydzy nietransgenicznej (Bt-). Zawartość białka kukurydzy Bt- była większa $(\mathrm{P}<0,05)$ niż $\mathrm{Bt}+$, lecz nie stwierdzono różnic $\mathrm{w}$ ilości rozłożonego białka oraz w tempie rozkładu białka między odmianami. Ilość białka kukurydzy Cry1Ab pozostająca po 16 i 24 godz. inkubacji w żwaczu wynosiła 85 i 60\%, odpowiednio.

Uzyskane wyniki wskazuja, że znaczna część białka Cry1 Ab nie była trawiona w żwaczu. Jest to pierwsze doniesienie dotyczące tempa rozkładu białka transgenicznego w żwaczu. 